\title{
The experience of women with abortion during adolescence as demanded by their mothers
}

\author{
Selisvane Ribeiro da Fonseca Domingos ${ }^{1}$ \\ Miriam Aparecida Barbosa Merighi ${ }^{2}$ \\ Maria Cristina Pinto de Jesus ${ }^{3}$ \\ Deíse Moura de Oliveira ${ }^{4}$
}

Objective: to understand the experience of women who induced an abortion during adolescence as demanded by their mothers. Method: qualitative study with a social phenomenology approach conducted in 2010 with three women through interviews with open questions. Results: the participants tried to hide their pregnancies from their mothers and when the mothers found out about the pregnancies they decide to interrupt it, demanding that their daughters have an abortion, which was performed in an unsafe manner, regardless of the adolescents' desire. After the abortion, the adolescents experienced suffering, guilt, and regret for not having fought against their mothers' decisions. These women expect to be autonomous to make their own decisions, take care of their own health and become pregnant again. Conclusion: the study evidenced the decision for an abortion was centered on the adolescents' mothers, a result that deserves to be further explored in future research deepening the relationship established between daughter and mother in the situation of an induced abortion. We suggest the creation of opportunities for the triad of health professional/adolescent/family to dialogue, especially the mother, who in the context of family relations, can help the daughter to safely deal with an early pregnancy and prevent it instead of influencing the adolescent to induce an abortion.

Descriptors: Induced, Abortion; Pregnancy in Adolescence; Women's Health; Qualitative Research.

\footnotetext{
${ }^{1}$ Post-doctoral fellow, Escola de Enfermagem, Universidade de São Paulo, São Paulo, SP, Brazil. 2 PhD, Full Professor, Escola de Enfermagem, Universidade de São Paulo, São Paulo, SP, Brazil.

${ }^{3} \mathrm{PhD}$, Associate Professor, Faculdade de Enfermagem, Universidade Federal de Juiz de Fora, Juiz de Fora, MG, Brazil.

${ }^{4}$ Doctoral student, Escola de Enfermagem, Universidade de São Paulo, São Paulo, SP, Brasil.
}

Corresponding Author:

Selisvane Ribeiro da Fonseca Domingos

Universidade de São Paulo. Escola de Enfermagem

Av. Dr. Enéas de Carvalho Aguiar, 419

Bairro: Cerqueira César

CEP: 05403-000, São Paulo, SP, Brasil

E-mail: selisvane@yahoo.com.br 


\section{Introduction}

Adolescent pregnancy is a complex phenomenon associated with economic and social factors, as well as sexual behavior. It has come to be considered an important public health problem due to its prevalence in recent decades ${ }^{(1)}$.

Approximately 15 million 15 to 19 year-old adolescents worldwide give birth every year, which represents more than $10 \%$ of all births ${ }^{(2)}$. At least 1.25 million adolescents become pregnant per year in the 28 members nations of the Organization for Economic Cooperation and Development (OECD). Of these, about half a million seek an abortion(3).

Data concerning adolescent pregnancy in Latin America show an increase in fertility rates for this population when compared to adult women, especially in poor countries(4). Recent Brazilian data show that there has been a faster decline in the number of births among adolescents in the last five years in the public health system. The number of abortions among 10 to 19 year-old adolescents dropped $22.4 \%$ from 2005 to 2009. The total drop was of $34.6 \%$ over that decade and such a reduction is attributed to campaigns directed to adolescents and increased access to family planning(5).

A study conducted in Colombia with 3,575 adolescents concluded that approximately one in each three participants presented risky sexual and/ or reproductive behaviors, including experiencing an unplanned pregnancy(6). An unplanned pregnancy that is also an unwanted pregnancy may pose a severe problem for the sexual and reproductive health of adolescents and young individuals, as assistance required due to abortions show ${ }^{(7)}$.

About 2.2 to 4 million adolescents worldwide undergo an abortion per year; $14 \%$ of these procedures are unsafe ${ }^{(2)}$. In Brazil, $7 \%$ to $9 \%$ of the total abortions are performed among women of reproductive age and, in most cases, among older adolescents (17 to 19 years old $)^{(8)}$.

A lack of debate concerning the specificity of pregnancy interruption favors a reductionist view concerning the meaning of this event at the beginning of the reproductive process, as the fact that the decision whether to continue a pregnancy or not involves a potential burden and potential risks when one opts for abortion is not taken into account. Therefore, the repercussions of an abortion in the lives of women go beyond those revealed by statistical data because an abortion is an event permeated with personal and social conflicts. The results of studies addressing the experiences of women with abortion show that the main reasons women opt for an abortion include economic difficulties in addition to a lack of support on the part of partners and/or family ${ }^{(9-10)}$.

From this context, the possibility emerges that abortion is a response of women to a lack of support or a decision imposed by those directly involved in the situation. This study focuses on the mother, whose bond with the adolescent and decision-power is cloaked with great significance and is capable of leading the adolescent to induce an abortion. The following concerns guided this study: How do women who induced an abortion during adolescence describe this experience? What factors influenced the decision for an abortion? What do they expect in relation to their reproductive life after this experience? Hence, we sought to understand the experience of women who induced an abortion during adolescence as demanded by their mothers.

Current Brazilian and international studies published in this periodical and that promote interfacing with the theme addressed in this study show scientific evidence focused on the social aspects concerning vulnerability that pervades adolescence, especially highlighting the use of drugs(11-12), domestic violence ${ }^{(13)}$, and sexual and reproductive health(6).

To the best of our knowledge, there are no recent studies addressing abortion during adolescence and the factors/people that impact this decision. Therefore, understanding the experience of abortion during adolescence as demanded by their mothers is an important contribution to knowledge produced regarding the theme in this periodical.

The results of this study will enable the identification of and reflection upon issues involved in the decision to have an abortion, focusing on the family perspective, which should be considered by professionals in the routine of health services.

\section{Methods}

This is a qualitative study grounded on the theoretical-methodological framework of the social phenomenology of Alfred Schütz. Such framework enables the understanding of human phenomena that occur in the world of life, also called the social world(14).

The theoretical assumptions of the world of life, body of knowledge, biographical situation, intersubjectivity, and social action, guided the discussion of results ${ }^{(14)}$. 
This study derives from a doctoral dissertation addressing seven women who experienced abortion during adolescence. For this study, however, we selected the experiences in which there was a demand on the part of mothers, using the testimonies of three women due to the relevance of their meanings.

Therefore, three women living in a city in the interior of Minas Gerais, Brazil were included in the study. These women were older than 18 years old, within the age range established by the World Health Organization (WHO) for the stage of life called adolescence, that is, from 10 to 20 years old(15). One of the researchers identified and selected the participants through informal conversations with people from the community who referred women who met the study's inclusion criteria and consented to participate.

Data were collected in 2010 through recorded interviews that addressed the following open questions: Would you please tell me how was it for you to learn that you were pregnant? How was it for you to decide to have an abortion and experience it? After experiencing it, what do you expect in relation to potential future pregnancies?

Interviews were scheduled in advance with each participant on the days, times and places chosen by them. The women received careful clarification regarding ethical issues before providing any testimonies and those who consented signed free and informed consent forms in accordance with Resolution 196/96, National Council of Health. To ensure confidentiality, the testimonies were identified by the letter " $T$ " followed by a number in crescent order according to the sequence of the interviews.

Data analysis followed the steps adopted by researchers in the tradition of the social phenomenology of Alfred Schütz ${ }^{(16)}$ : reading; detailed re-reading of each testimony to grasp the experience's global meaning; identification and later grouping of the significant aspects of testimonies to compose concrete categories - objective syntheses of different meanings of actions that emerged from experiences; analysis of these categories; and discussion of results based on the social phenomenology of Alfred Schütz and related studies.

The study's participants were 18 to 27 years old, single, with incomplete high school. Pregnancies were interrupted between 14 and 16 years old. At the time, they lived with their mothers, on whom they depended financially. All reported the desire to continue their pregnancy, even though they had not planned it.

This study was submitted to and approved by the Institutional Review Board at the University of São Paulo, School of Nursing (Process No. 909/2010).

\section{Results}

The experience of women who induced abortion during adolescence as demanded by their mothers is portrayed in the categories: "abortion as demanded by their mothers" and "autonomy in reproductive life" as shown below:

\section{Abortion as demanded by mothers}

When reflecting upon their pregnancies during adolescence, the women recalled feelings of insecurity and despair from experiencing an unplanned event. Their reports show they feared their mothers would not accept their pregnancies: I knew I was pregnant but kept it quiet [...] I thought my mother would kill me (T2). My period was late and then I knew I was pregnant [...]. I was in a very difficult situation because I could not tell my mom (T3).

Desperate in the face of the new situation since they did not know how to disclose the pregnancy to their mothers, these young women initially shared the news with a trusted friend, boyfriend, or the father of the fetus, and tried to hide the pregnancy: I tried to hide it from my mother as long as I could [...] I knew she wouldn't accept it. (T2). I told a friend of mine. [...] Then I told my mother and she didn't accept the pregnancy (T3).

However, the progress of the gestational process manifested by the changes that occurred in the adolescents' bodies led the mothers to perceive that something was happening to their daughters and to realize they were hiding a pregnancy: she (mother) wanted to know the day I was supposed to get my period [...] she said I was too chubby (T1).

In this context, the mothers demanded that their daughters take a pregnancy exam and as soon as the pregnancy was confirmed, they decided to interrupt it, regardless of the adolescents' desire: I left home one day and when I came back my mother had a pharmacy pregnancy test for me (T1). [...] she took me to take an exam and it was positive [...]. At that very moment, [...] she told me I couldn't have that child (T2).

Despite their desire not to interrupt their pregnancy, the adolescents reported they had no autonomy to make that decision, they were forced to comply with their mothers' decision: [...] my mother said that I could not have that child and told me that we'd buy some medication. [...] I said that I wouldn't do it but I lived with her, I was 16 years old and was a minor, so I couldn't do much (T2).

The abortion imposed by the mother was reported by the participants as a moment of suffering because they were physically and psychologically abused. Their 
mothers forced them to drink special teas and take abortive medication in their own homes: [...] she (mother) [...] went to the drugstore to buy medication [...] she made me take a pill and shoved down the other. I told her that I would not do it, but, I lived with her, was too young and had no other option. [...] I felt much pain. I wanted to die (T2). My mother gave me 'buchinha do norte'*, tea pot, cachaça prepared with cinnamon. None of these worked and I ended up in the hospital. [...] I got pretty sick [...] almost died (T3).

Because the abortion process did not happen the way they expected, the mothers had to seek medical care to save the lives of their daughters, who experienced severe complications and faced the risk of death: $I$ was bleeding so much that I was almost dead. So, my mother had to call the emergency service (T3).

After the abortion, the adolescents experienced suffering and frustration for not having fought against their mothers' decision. Their lack of autonomy and power to decide about their own bodies and health could be read between the lines of the reports of these young women, revealing the difficulties they faced during this experience: [...] It took a while for me to realize it. [...] I felt guilty [...]. Today, when I think about all I've done, I feel bad. [...] I feel angry with my mom and with myself. I should have fought harder. (T1). It was really sad [...]. It is not easy take someone's life. [...] I cry to this day. [...] I think that if I didn't want to, I didn't need to drink those teas, but I did (T3). As a consequence, they currently seek to have autonomy over their reproductive lives.

\section{Autonomy in reproductive life}

Reflecting upon the abortion they experienced during adolescence caused these women to expect the possibility of being able to make their own decisions without the interference of their mothers and families. As a response to this desire, they plan a new pregnancy, acknowledging that, for that, they first need to take care of their health: I want to get married and have a child. [...] I want to take care of myself. [...] (T1) It was difficult to go back to normal life. You become afraid of getting pregnant again [...] I think about having a child but not now (T2). I think about having more children [...] Now, my mother cannot stop me because I've reached the age of majority (T3).

As a response to the need to manage their own choices and decisions, women have as a project actions in which they take responsibility for their lives, which is expressed by their desire to go back to work and school: [...] I want to keep studying (T1). Now I think about working (T3).

\section{Discussion}

An abortion during adolescence given a demand on the part of mothers indicates there is a need to pay attention to issues related to interpersonal communication and decisions concerning reproductive life, since none of the participants expected to become pregnant.

The participants manifested a fear of the possibility of their mothers not accepting their pregnancies. Such refusals to accept the adolescents' pregnancies may be a consequence of their disappointment with the un-expected event, considering that the family and social context requires that young people fulfill ideal trajectories and follow predetermined stages, such as concluding studies and becoming professionals, a view that identifies an pregnancy as inopportune and unwise $^{(17)}$. A pregnancy at this time in life is considered to be a threat ${ }^{(18)}$ because it not only compromises and changes the structure of families but also compromises the dreams and needs inherent to adolescents living in modern society ${ }^{(19)}$.

In the family sphere, a pregnancy seems to indicate the existence of difficulties in the relationship between parents and daughters and in the contextual conditions for their psychological development ${ }^{(18)}$. Young women who are self-assured and able to act according to their standards of right and wrong are the ones who value and manifest the affection they receive from the family. From there, we say that respect for standards and rules depends on how much we have to lose in terms of affection, care, and protection and that the relationship of authority is maintained due to affective exchanges ${ }^{(20)}$.

The conflicts experienced between adolescents and their mothers in the face of a pregnancy show the power of a body of knowledge that is built upon previous experiences of decisions that are made at the individual level but that also have a social nature, since the person is included in a system of inter-subjective relationships in the world of life. Such a world of life is composed of the individual's experiences, which is previously structured even before one's birth. It is the setting in which human beings live and interact with others, continually transforming and changing social structures ${ }^{(14)}$.

The mothers' decisions to interrupt the adolescents' pregnancies through an abortion portrays a lack of communication in the family context; at the same time

\footnotetext{
* Popular name in Brazil for Luffa Operculata.
} 
it shows the adolescents' fragility, evidenced by their lack of autonomy.

Few families accept adolescent pregnancies and deal with them with understanding and affection, respecting the pregnant adolescents' limitations. Most impose a marriage, even if the adolescents do not want to marry, forcing the adolescents to give up desires and expectations. Other families impose abortion, abandonment or use violence. Many parents expel their daughters from the home, aggravating the problems these young women will have to face ${ }^{(19)}$.

According to a study conducted in the interior of São Paulo with families of pregnant adolescents, the frustration of having a family life project interrupted and/or changed permanently was manifested in the representations concerning the changes that took place in the family context after the pregnancies of adolescents who were single at the time of conception(21).

The fact the mothers demanded that their daughters abort their pregnancies leads to reflections on the reasons that triggered these decisions. A relevant issue is the possibility of an early pregnancy interrupting the adolescent's educational process, forcing her to leave school and hindering her inclusion in the job market ${ }^{(22)}$. Other issues include difficult family dialogue, difficulty sharing feelings and a lack of guidance regarding sexual and reproductive health. When parents lack information or feel uncomfortable addressing sex with their children, they end up not playing their educational role and not transmitting appropriate sexual guidance, leaving young individuals at a disadvantage ${ }^{(19)}$.

Currently a great part of family problems are due to a lack of dialogue between parents and children, especially among families with adolescents, since agespecific conflicts tend to worsen family confrontations. In this context, the authority of parents over children requires greater flexibility and balance in order to preserve family harmony and ensure that adolescents feel safe ${ }^{(23)}$.

In regard to the mother's role, even though women have entered the job market and perform an increasing number of activities outside home, domestic duties, especially the education of children, are still functions primarily performed by mothers. The results of a study conducted in Porto Alegre, Brazil with adolescent students confirm such a statement; most participants reported talking more with their mothers $(75 \%)^{(23)}$.

Therefore, the fact that women occupy both public and private spaces does not cause them to abdicate their caregiver role and this may be an explanation why the mother is the main aggressor when it comes to physical violence and neglect of children and adolescents $^{(13)}$.

In this sense, abortion is a complex phenomenon permeated by ethical, cultural and religious issues. Moreover, when abortions are hidden and performed in an unsafe manner, they become an important public health problem that is internationally recognized because they can lead to severe sequelas or even to death(24).

The women addressed in this study felt guilty and regretted the fact they did not fight against their mothers' decision because, even though they had not planned their pregnancies, they wanted to have the children. These adolescents, however, did not consider themselves to deserve punishment because they were minors and financially dependent on the family. Additionally, they did not think they were able to resist their mothers' decisions. These feelings may be related to how abortion is seen socially and, therefore, how it is embodied in their store of knowledge.

Such body of knowledge depends on the individual's biographic situation, which is inter-subjectively constituted and established based on one's natural conception of the world of life. It is imposed on the person who internalizes habits, customs, traditions, though it can be reconsidered and changed at any time ${ }^{(14)}$.

Not only do they experience suffering permeated by the guilt and regret having induced abortions, these women also reported physical and psychological consequences. According to a study conducted in New Zealand, women who induced abortion experienced high rates of depression, anxiety and suicidal thoughts ${ }^{(25)}$. This result, however, is challenged by a Danish cohort study that reports a rate of incidence of psychiatric contact that is similar before and after abortion, refuting the hypothesis of an increased risk of mental disorders after an abortion ${ }^{(26)}$.

Those who oppose the legalization of abortion suggest that this is a traumatic event with severe consequences for the mental health of women. Nonetheless, a study derived from a report of the American Psychological Association does not report any evidence that an abortion causes mental health problems in adult women(27). The fact is that unsafe abortion methods are an important cause of morbidity and mortality among women in developing countries. In addition to the consequences already presented, we highlight those of an economic nature related to costs from medical care, loss of productivity for the country, and the impact on families and the community ${ }^{(28)}$. 
Reflecting on the experience expressed by the impact of a pregnancy, abortion, and related suffering and related consequences caused feelings and meanings to emerge that compose the objective context of motives that characterize the social behavior of a group of women who experienced abortion during adolescence as demanded by their mothers.

Note that social action, that is, the human behavior consciously and intentionally projected by the subject, is inserted into a historical dimension and is not linked only to the past but opens up to the future. That is, it includes freedom, so that success and failure are equally possible. Hence, the projection of intentions has a subjective dimension, since it triggers an action before it becomes an $\operatorname{act}^{(14)}$, which leads us to the conclusion that the abortion that took place in the past permeates the present and influences the projects of these women in the present.

Therefore, the women who interrupted a pregnancy due to the decision of their mothers seek independence to make their own decisions without the interference of their family; they also desire to become pregnant again.

In relation to health care, adolescents and young individuals have the right to access information and obtain education in regard to sexual and reproductive health, as well as contraceptive methods to help them avoid unplanned pregnancies and sexually transmitted diseases (STDs), respecting their freedom to choose(29).

Additionally, the decision to induce an abortion is directly related to the reproductive lives of women, thus, they are able to determine whether a pregnancy will continue or be interrupted. Thus, reflecting upon the experience of abortion, even if it is distant for some and more recent for others, such an experience can influence how women plan their reproductive lives.

The understanding of the experience of abortion during adolescence takes place from certain perspectives, enabling different points of view to clarify facets of a given social phenomenon. In this sense, this study provides evidence that reveal the experience of abortion during adolescence based on a specific group of women who performed such an act as demanded by their mothers.

\section{Final Considerations}

The knowledge that emerged from the experience of women who experienced abortion during adolescent as demanded by their mothers indicates there is a need to review health actions directed to this dyad. Despite the advancements achieved in the last decades, especially in relation to sexual and reproductive health, many women still become pregnant without planning to do so and do not have the necessary family support to deal such an event.

The demands of mothers resulting in their adolescent daughters having abortions, as shown in this study, constitutes new information that deserves further exploration in scientific investigations. In general, studies conducted so far have addressed early pregnancies and their repercussions on the family and social context, without however, deepening the social relationship between mother and daughter concerning the possibility and decision to induce an abortion.

This study shows the need to include the family, especially the mothers, in actions designed to prevent adolescent pregnancy and also in situations when a pregnancy does occur, especially when the possibility of an abortion is considered.

Considering the focus of the social phenomenology used in this study, we suggest that the creation of opportunities for the triad of health professional/ adolescent/family, especially for the mother, to dialogue in the context of family relations, can help adolescents to safely deal with an early pregnancy and prevent it, instead of influencing them to induce an abortion.

\section{References}

1. Chalem E, Mitsuhiro SS, Ferri CP, Barros MCM, Guinsburg R, Laranjeira R. Gravidez na adolescência: perfil sócio-demográfico e comportamental de uma população da periferia de São Paulo, Brasil. Cad Saúde Pública. 2007;23(1):177-86.

2. World Health Organization (WHO). Pregnant adolescents: delivering on global promises of hope. 2006. [acesso 4 set 2011]. Disponível em: http://www.who.int/ child_adolescent_health/documents/9241593784/en/.

3. Fundo das Nações Unidas para a Infância (UNICEF). Situação mundial da infância 2011. Adolescência: uma fase de oportunidades. Caderno Brasil. [acesso 10 maio 2011]. Disponível em: http://www.unicef.org.br.

4. Cerqueira-Santos E, Paludo SS, Dei Schirò EDB, Koller SH. Gravidez na adolescência: análise contextual de risco e proteção. Psicol Estudos. 2010;15(1):73-85.

5. Ministério da Saúde (BR). Brasil acelera redução de gravidez na adolescência. 2010. [acesso 30 set 2011]. Disponível em: http://portal. saude.gov.br/portal/aplicacoes/noticias/default. cfm?pg=dspDetalheNoticia\&id_area $=124 \& C O$ NOTICIA $=11137$. 
6. Campo-Arias A, Ceballo Guillermo A, Herazo E. Prevalence of Pattern of Risky Behaviors for Reproductive and Sexual Health Among Middle- and High-School Students. Rev. Latino-Am. Enfermagem. 2010 Abr; 18(2): 170-4.

7. Ministério da Saúde (BR). Secretaria de Atenção

à Saúde. Marco teórico e referencial: saúde sexual e saúde reprodutiva de adolescentes e jovens. Brasília; 2006.

8. Ministério da Saúde (BR). Secretaria de Ciência, Tecnologia e Insumos Estratégicos. Departamento de Ciência e Tecnologia. 20 Anos de Pesquisas sobre Aborto no Brasil. Brasília; 2009.

9. Carvalho SM, Paes GO, Leite JL. Mulheres jovens e o processo do aborto clandestino: uma abordagem sociológica. Rev Saúde Sexual e Reprodutiva. 2011;52:1-18.

10. Vieira LM, Goldberg TBL, Saes SO, Dória AAB. Abortamento na adolescência: da vida à experiência do colo vazio - um estudo qualitativo. Ciência Saúde Coletiva. 2010;15 Suppl 2:3149-56.

11. Cid-Monckton P, Pedrao LJ. Factores familiares protectores y de riesgo relacionados al consumo de drogas en adolescentes. Rev. Latino-Am. Enfermagem. 2011;19 Suppl:738-45. 12. Garcia JJ, Pillon SC, Santos MA. Relações entre contexto familiar e uso de drogas em adolescentes de ensino médio. Rev. Latino-Am. Enfermagem. 2011;19 Suppl:753-61.

13. Apostólico MR, Nóbrega CR, Guedes RN, Fonseca RMGS, Egry EY. Características da violência contra a criança em uma capital brasileira. Rev. Latino-Am. Enfermagem. 2012;20(2):266-73.

14. Schutz A, Luckmann T. Las estructuras del mundo de la vida. Buenos Aires: Amorrortu; 2009.

15. Organización Mundial de la Salud (OMS). Problemas de salud de la adolescencia. Ginebra: OMS; 1965. (Série de Informes técnicos).

16. Carvalho GM, Merighi MAB, Jesus MCP. The experience of repeated fatherhood during adolescence. Midwifery. 2010;26:469.74.

17. Peres So, Heilborn ML. Cogitação e prática do aborto entre jovens em contexto de interdição legal: o avesso da gravidez na adolescência. Cad Saúde Pública. 2006;22(7):1411-20.

18. Rodrigues DP, Rodrigues FRA, Silva LMS, Jorge MSB, Vasconcelos LDGP. O adolescer e ser mãe. Representações sociais de puérperas adolescentes. Cogitare Enferm. 2009;14(3):455-62.

19. Moreira TMM, Viana DS, Queiroz MVO, Jorge MSB. Conflitos vivenciados pelas adolescentes com a descoberta da gravidez. Rev EsC Enferm USP. 2008;42(2):312-20.

20. Taquete SR, Vilhena MM. Uma contribuição ao entendimento da iniciação sexual feminina na adolescência. Psicol Estudos. 2008;13(1):105-14.

21. Silva L, Tonete VLP. A gravidez na adolescência sob a perspectiva dos familiares: compartilhando projetos de vida e cuidado. Rev. Latino-Am. Enfermagem. 2006;14(2):199-206.

22. Andrade PR, Ribeiro CA, Ohara CVS. Maternidade na adolescência: sonho realizado e expectativas quanto ao futuro. Rev Gaúcha Enferm. 2009;30(4):662-8.

23. Wagner A, Falcke D, Silveira LMBO, Mosmann CP. A comunicação em famílias com filhos adolescentes. Psicol Estudos. 2002;7(1):75-80.

24. Rede Nacional Feminista de Saúde e Direitos Reprodutivos - (RedeSaúde). Dossiê - Aborto inseguro. [acesso 25 out 2011]. Disponível em: http:// www. observatoriodegenero.gov.br/.../dossie-abortoinseguro/at.../file

25. Fergusson DM, Horwood LJ, Ridder EM. Abortion in young women and subsequent mental health. J Child Psychol Psychiatry. 2006;47:16-24.

26. Munk-Olsen T, Laursen TM, Pedersen CB, Lidegaard O, Mortensen PB. Induced first-trimester abortion and risk of mental disorder. N Engl J Med. 2011;364(4):332-9.

27. Warren JT, Harvey SM, Henderson JT. Do depression and low self-esteem follow abortion among adolescents? Evidence from a national study. Perspect Sexual Reproductive Health. 2010;42(4):230-5.

28. Singh S. Global consequences of unsafe abortion. Womens Health (Lond Engl) 2010;6(6):849-60.

29. Ministério da Saúde (BR). Secretaria de Atenção à Saúde. Departamento de Ações Programáticas Estratégicas. Direitos sexuais, direitos reprodutivos e métodos anticoncepcionais. Brasília; 2009.
Received: July $31^{\text {st }} 2012$ Accepted: Apr. 22 2013 